\title{
Prediction of Growth and Yield of Late Sown Wheat Using DSSAT (v4.5) Model under Western Zone of Haryana
}

\author{
Mukesh Kumar ${ }^{1}$, R.K. Pannu ${ }^{1}$, Raj Singh ${ }^{2}$, Bhagat Singh ${ }^{1}$, A.K. Dhaka ${ }^{1}$ and Rajeev $^{2}$ \\ ${ }^{1}$ Department of Agronomy, College of Agriculture, CCS Haryana Agricultural University, \\ Hisar-125004 (Haryana), India \\ ${ }^{2}$ Department of Agricultural Meteorology, College of Agriculture, CCS Haryana \\ Agricultural University, Hisar-125004 (Haryana), India \\ *Corresponding author
}

\section{A B S T R A C T}

\section{Keywords}

DSSAT,

Calibration,

Validation, Late

sown wheat,

Irrigation levels,

Nitrogen levels.

Article Info

Accepted:

24 February 2017

Available Online:

10 March 2017
The aim of this study was the calibration and validation of DSSAT model (v4.5) for late sown wheat in western zone of Haryana. The DSSAT model was calibrated with the field experimental data of rabi 2010-11 having 3 levels of irrigation (one irrigation at crown root initiation [CRI], two irrigations at CRI and heading and four irrigations at CRI, late tillering, heading and milking) and 5 nitrogen levels $(0,50,100,150$ and $200 \mathrm{~kg} \mathrm{~N} / \mathrm{ha}$ ) and validated with data of experiment rabi 2011-12 conducted at Hisar $\left(29^{\circ} 10^{\prime} \mathrm{N}\right.$ and $\left.75^{\circ} 46^{\prime} \mathrm{E}\right)$. The model performance was evaluated using average error (Bias), root mean square error (RMSE), normalized root mean square error (nRMSE), index of agreement (d-stat) and coefficient of determination $\left(\mathrm{r}^{2}\right)$, and it was observed that DSSAT model was able to predict the growth parameters (maximum leaf area index and total effective tillers), yields (grain, straw and biomass) and harvest index with reasonably good accuracy (error $\%$ less than \pm 15 ).

\section{Introduction}

Wheat (729.8 million tons) is second to rice as the main human food crop (FAO, 201415). In India, wheat is cultivated extensively in North-Western and Central zones. The area, production and productivity of wheat in India and Haryana during 2014-15 is 31.46 mha, $86.53 \mathrm{mt}, 2749 \mathrm{~kg} \mathrm{ha}^{-1}$ and $2.60 \mathrm{mha}$, $10.35 \mathrm{mt}, \quad 3980 \mathrm{~kg} \mathrm{ha}^{-1}$, respectively (Anonymous, 2014-15). Late sowing of wheat is a major problem in the rice-wheat and cotton-wheat cropping system (Khan et al., 2010). Late sowing wheat face low temperature in the earlier part and high temperature stress in the later part of the growing season (Alam et al., 2013).

Crop growth simulation models provide the means to qualify the effects of climate, soil, management on crop growth, productivity and sustainability of agricultural production (Nain and Kersebaum, 2007). Among the numerous crop growth models, the most widely used are the DSSAT (Decision Support System for Agrotechnology Transfer) crop growth model, has been in use for more than 20 years which integrates the effects of soil, weather, and 
management (Jones et al., 2003). DSSAT grew out of the International Benchmark Sites Network for agrotechnological Transfer (IBSNAT) in the 1980s, with the first official released in 1989 (DSSATv2.1). DSSAT was developed in University of Hawaii, Honolulu, Hawaii in United States (USA). The DSSAT model offers wide opportunities for studies of interactions between plants and ambient, nitrogen, plant varieties, irrigation, carbon (Thorp et al., 2008). To find an effective way to save water in the wheat-growing season without markedly reducing wheat yield, DSSAT-wheat was calibrated, validated and used to simulate water use by winter wheat (Yang et al., 2006). The DSSAT model can be used for a variety of tasks in simulating water regime and nitrogen doses.

In India, the DSSAT-CSM-CERES-Wheat v4.0 model was calibrated using the historical weather data of a 36 year period (1970-2005) to estimate the long-term mean and variability of potential yield, drainage, runoff, evapotranspiration, crop water productivity and irrigation water productivity (Timsina et al., 2008). This capability of DSSAT model makes it more suitable to predict response of the complex system affected by many factors such as crop growth and crop yield in wake of variable soil potential (Solaimani, 2009). Validation of crop dynamic model for any crop and any area will be greater applicable to predict the crop growth parameters as well as yield components in advance which are important for planning as well as management.

The scientific information on crop growth modeling under different growing conditions on wheat crop in Haryana state is limited. Hence, keeping all these points in view, the present investigation entitled "Prediction of growth and yield of late sown wheat using DSSAT (v4.5) model under western zone of Haryana" was undertaken.

\section{Materials and Methods}

An experiment was conducted during 2010-11 and 2011-12 at CCS Haryana Agricultural University, Hisar (India) to study prediction of growth and yield of late sown wheat using DSSAT (v4.5) model under western zone of Haryana located in Indo-Gangetic plains of North-West India with a latitude of $29^{0} 10^{\prime}$ North and longitude of $75^{\circ} 46^{\prime}$ East at 215.2 meters above mean sea level. The soil of the field was sandy loam, having $0.39 \%$ OC and $\mathrm{pH}$ 7.95. It was low in available $\mathrm{N}$ (156.1 $\mathrm{kg} / \mathrm{ha})$, medium in available $\mathrm{P}(10.5 \mathrm{~kg} / \mathrm{ha})$ and rich in available $\mathrm{K}(306.4 \mathrm{~kg} / \mathrm{ha})$. The experiment consisting of three irrigation frequencies viz. one irrigation at $\mathrm{CRI}\left(\mathrm{I}_{1}\right)$, two irrigations at CRI and heading $\left(\mathrm{I}_{2}\right)$ and four irrigations at CRI, late tillering, heading and milking $\left(\mathrm{I}_{3}\right)$ in main plots and five nitrogen doses viz. control i.e. $0 \mathrm{~kg} \mathrm{~N} / \mathrm{ha}\left(\mathrm{F}_{0}\right), 50 \mathrm{~kg}$ $\mathrm{N} / \mathrm{ha}\left(\mathrm{F}_{1}\right), 100 \mathrm{~kg} \mathrm{~N} / \mathrm{ha}\left(\mathrm{F}_{2}\right)$, recommended dose of nitrogen i.e. $150 \mathrm{~kg} \mathrm{~N} / \mathrm{ha}\left(\mathrm{F}_{3}\right)$ and 200 $\mathrm{kg} \mathrm{N} / \mathrm{ha}\left(\mathrm{F}_{4}\right)$ in sub-plots was laid out in strip plot design with four replications. Nitrogen was applied in the form of urea during both the year. Nitrogen was applied in two splits: Half of the nitrogen was applied as basal and half as top dressed after $1^{\text {st }}$ irrigation. The recommended dose of phosphorus $(60 \mathrm{Kg}$ $\mathrm{P}_{2} \mathrm{O}_{5} \mathrm{ha}^{-1}$ ) was applied through di-ammonium phosphate (DAP) at time of sowing while in control treatment phosphorous was applied in the form of single super phosphate (SSP). Wheat $c v$. WH 1021 was sown with the help of seed drill in rows $18 \mathrm{~cm}$ apart at the rate of $125 \mathrm{~kg} / \mathrm{ha}$. Crop was sown on $18^{\text {th }}$ December during both the years of the experimentation. Irrigation was applied in the field as per treatments. The weeds were removed by long tine hoe at 40 days and later by hand pulling.

The DSSAT model requires daily weather data of maximum and minimum air temperature $\left({ }^{\circ} \mathrm{C}\right)$, solar radiation $\left(\mathrm{k} \mathrm{Jm}^{-2} \mathrm{~d}^{-1}\right)$, vapour pressure $(\mathrm{kPa})$, wind speed $\left(\mathrm{ms}^{-1}\right)$ and 
rainfall $(\mathrm{mm})$. The daily meteorological data were recorded at the agro-meteorological observatory located near to the Research Farm of Chaudary Charan Singh Haryana Agricultural University, Hisar.

\section{Calibration of the model}

The latest version of DSSAT is DSSATv4.5, which we used in our calibration and validation was developed in 2010. Calibration of model involves adjusting certain model parameters or relationships to make the model work for any desired location. The model requires cultivar specific genetic coefficients. The details of these coefficients are given in Table 1. For calibration of DSSAT model one year (2010-11) data set was used and for validation, data sets of 2011-12 experiments were used. Validation of model was done by using data sets on total no. of effective tillers, LAI, biomass, grain yield and harvest index from experiments conducted at Research Farm Hisar.

\section{Model validation}

To test the accuracy of model with the cultivar used the model was run with observed crop management data from field, weather and soil data and calibrated cultivar genotypic coefficients, the predicted wheat grain yield were compared with actual grain yield.

Different statistical tools were used to evaluate the performance of the model in predicting various parameters. The statistical analysis of Ambrose and Rosech (1982) was used to calculate the average error or Bias (Eqn. 1) and root mean square error (Eqn. 2) between the simulated and observed values. Normalized RMSE (nRMSE) gives a measure (\%) of the relative difference of simulated versus observed data. The simulation is considered excellent with a normalized
RMSE (Eqn. 3) is less than 10\%, good if the normalized RMSE is greater than $10 \%$ and less than $20 \%$, fair if normalized RMSE is greater than 20 and less than $30 \%$, and poor if the normalized RMSE is greater than 30\% (Jamieson et al., 1991). $\mathrm{M}$ is the mean of observed variable.

The index of agreement (d) proposed by Willmott et al. (1985) was estimated in (Eqn.4). According to the d-statistic, the closer the index value is to one, the better the agreement between the two variables that are being compared and vice versa.

Bias $=\sum_{i=1}^{n} \frac{\left(S_{i}-O_{b}\right)}{n} \quad$ Eqn. 1

RMSE $=\sqrt{\sum_{i=1}^{n} \frac{\left(S_{i}-O b\right)^{n}}{n}} \quad$ Eqn. 2

nRMSE $=\sqrt{\sum_{i=1}^{n} \frac{(S i-O b)^{n}}{n}} \times \frac{100}{M} \quad$ Eqn. 3

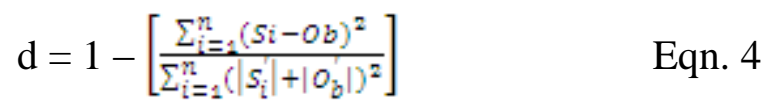

Besides the above test criteria, error percent was also calculated in different treatment under study to express the deviation more scientifically.

This is as follows:

Error $\%=\{(\mathrm{Si}-\mathrm{Ob}) / \mathrm{Ob}\} * 100$

Whereas,

$S_{i}^{i}=\mathrm{Si}-\mathrm{M}$

$\mathrm{O}_{b}=\mathrm{Ob}-\mathrm{M}$

$\mathrm{n}$, is the number of observations

$\mathrm{Si}$, is the simulated values

$\mathrm{Ob}$, is the observed values

$\mathrm{M}$ is the mean of observed variable 


\section{Results and Discussion}

\section{Comparison of grain yield}

The grain yield was simulated by the calibrated DSSAT model. Mean measured grain yield of wheat ranged between $1498 \mathrm{~kg}$ ha $^{-1}\left(\mathrm{I}_{1} \mathrm{~F}_{0}\right)$ to $4791 \mathrm{~kg} \mathrm{ha}^{-1}\left(\mathrm{I}_{3} \mathrm{~F}_{4}\right)$ among irrigation levels and dose of nitrogen combinations in 2011-12, while model simulated grain yield ranged $1249 \mathrm{~kg} \mathrm{ha}^{-1}$ $\left(\mathrm{I}_{1} \mathrm{~F}_{0}\right)$ to $5012 \mathrm{~kg} \mathrm{ha}^{-1}\left(\mathrm{I}_{3} \mathrm{~F}_{4}\right)$ (Table 2 and fig. 1a). The model underestimated the grain yield at lower doses of fertilizer i.e. $0 \mathrm{~kg} \mathrm{Nha}^{-1}$ and $50 \mathrm{~kg} \mathrm{Nha}^{-1}$ and overestimated at higher doses of fertilizer i.e. 150 and $200 \mathrm{~kg} \mathrm{~N}^{-1}$ at all the irrigations levels. Error percent ranged between $-16.62\left(\mathrm{I}_{1} \mathrm{~F}_{0}\right)$ to $11.89\left(\mathrm{I}_{2} \mathrm{~F}_{4}\right)$. The calculated values of statistical indices, average error (Bias), root mean square error (RMSE), normalized RMSE (nRMSE), index of agreement (d) and coefficient of determination $\left(\mathrm{r}^{2}\right)$ were $-3.93 \mathrm{~kg} \mathrm{ha}^{-1}, 226.3$ $\mathrm{kg} \mathrm{ha}^{-1}, 6.81 \%, 0.99$ and 0.97 , respectively.

The error was within range i.e. +15 to $-15 \%$ in all combinations of irrigation and dose of nitrogen. DSSAT underestimated the results at lower dose of nitrogen or without nitrogen application because of poor response of DSSAT without nitrogen, but at higher doses of nitrogen DSSAT responded very well. The calculated values of statistical indices, average error (Bias), root mean square error (RMSE), normalized RMSE (nRMSE), index of agreement (d) and coefficient of determination was quite well during 2011-12. Generally, the simulation is considered excellent with a normalized RMSE is less than $10 \%$, good if the normalized RMSE is greater than $10 \%$ and less than $20 \%$, fair if normalized RMSE is greater than 20 and less than $30 \%$, and poor if the normalized RMSE is greater than $30 \%$. According to the $\mathrm{d}$ statistic, the closer the index value is to one, the better the agreement between the two variables that are being compared and vice versa. Similarly, the closer the $r^{2}$ value is to one showed a good match between two variables. Similar results have been reported by Timsina et al., 2008 and Andarzian et al., 2014. Aforementioned indexes imply the robustness of the model in simulating wheat yields and harvest index of wheat.

\section{Comparison of biomass of late sown wheat}

The biological yield was simulated by the calibrated DSSAT model. Mean measured biological yield of wheat varied from $4616 \mathrm{~kg}$ ha $^{-1}\left(\mathrm{I}_{1} \mathrm{~F}_{0}\right)$ to $11372 \mathrm{~kg} \mathrm{ha}^{-1}\left(\mathrm{I}_{3} \mathrm{~F}_{4}\right)$ among irrigation levels and dose of nitrogen combinations in 2011-12, while model simulated biological yield ranged between $4184 \mathrm{~kg} \mathrm{ha}^{-1}\left(\mathrm{I}_{1} \mathrm{~F}_{0}\right)$ to $11856 \mathrm{~kg} \mathrm{ha}^{-1}\left(\mathrm{I}_{3} \mathrm{~F}_{4}\right)$ (Table 2 and Fig. 1b). The model underestimated the biological yield at lower doses of fertilizer i.e. $0 \mathrm{~kg} \mathrm{Nha}^{-1}$ and $50 \mathrm{~kg}$ $\mathrm{Nha}^{-1}$ and overestimated at higher doses of fertilizer i.e. 150 and $200 \mathrm{~kg} \mathrm{~N}^{-1}$ at all the irrigations levels during both the years of study. Error percent ranged between -11.61 $\left(\mathrm{I}_{2} \mathrm{~F}_{0}\right)$ to $10.17 \quad\left(\mathrm{I}_{1} \mathrm{~F}_{4}\right)$, respectively. The calculated values of statistical indices viz., average error (Bias), root mean square error (RMSE), normalized RMSE (nRMSE), index of agreement (d) and coefficient of determination $\left(\mathrm{r}^{2}\right)$ were $86.32 \mathrm{~kg} \mathrm{ha}^{-1}, 463.6$ $\mathrm{kg} \mathrm{ha}^{-1}, 5.38 \%, 0.99$ and 0.98 , respectively.

\section{Comparison of straw yield of late sown wheat}

The straw yield was simulated by the calibrated DSSAT model. Mean measured straw yield of wheat varied from $3118 \mathrm{~kg} \mathrm{ha}^{-1}$ $\left(\mathrm{I}_{1} \mathrm{~F}_{0}\right)$ to $6581 \mathrm{~kg} \mathrm{ha}^{-1}\left(\mathrm{I}_{3} \mathrm{~F}_{4}\right)$ among irrigation levels and dose of nitrogen combinations in 2011-12, while model simulated straw yield ranged between $2935 \mathrm{~kg} \mathrm{ha}^{-1}\left(\mathrm{I}_{1} \mathrm{~F}_{0}\right)$ to $6844 \mathrm{~kg}$ $\mathrm{ha}^{-1}\left(\mathrm{I}_{3} \mathrm{~F}_{4}\right)$ (Table 2 and Fig. 1c). Similarly, like grain yield and biological yield, the 
model underestimated the straw yield at lower doses of fertilizer i.e. $0 \mathrm{~kg} \mathrm{Nha}^{-1}$ and $50 \mathrm{~kg}$ $\mathrm{Nha}^{-1}$ and overestimated at higher doses of fertilizer i.e. 150 and $200 \mathrm{~kg} \mathrm{~N}^{-1}$ at all the irrigations levels during both the years of study. Error percent ranged between -10.22 $\left(\mathrm{I}_{2} \mathrm{~F}_{0}\right)$ to $9.17\left(\mathrm{I}_{1} \mathrm{~F}_{4}\right)$. The calculated values of statistical indices, average error (Bias), root mean square error (RMSE), normalized RMSE (nRMSE), index of agreement (d) and coefficient of determination $\left(\mathrm{r}^{2}\right)$ were 90.25 $\mathrm{kg} \mathrm{ha}^{-1}, 271.2 \mathrm{~kg} \mathrm{ha}^{-1}, 5.12 \%, 0.99$ and 0.98 .

Table.1 Genetic coefficients of DSSAT-wheat model (v4.5) for Hisar conditions (variety- WH 1021)

\begin{tabular}{|c|c|c|}
\hline PARAMETERS & DESCRIPTION OF PARAMETERS & values \\
\hline P1V & $\begin{array}{l}\text { Vernalization sensitivity coefficient: Relative amount that } \\
\text { development is slowed for each day of unfulfilled } \\
\text { vernalization, assuming that } 50 \text { days of vernalization is } \\
\text { sufficient for all cultivars }\end{array}$ & 1 \\
\hline P1D & $\begin{array}{l}\text { Photoperiod sensitivity coefficient (\% reduction/h near } \\
\text { threshold): Relative amount that development is slowed } \\
\text { when plants are grown in one hour photoperiod shorter than } \\
\text { the optimum (which is considered to be } 20 \text { hours) }\end{array}$ & 73 \\
\hline P5 & $\begin{array}{l}\text { Grain filling duration coefficient [(Thermal time from the } \\
\left.\text { onset of linear fill to maturity }\left({ }^{\circ} \mathbf{C ~ d}\right)\right] \text { : Degree days above a } \\
\text { base of } 1{ }^{\circ} \mathrm{C} \text { from } 20^{\circ} \mathrm{C} \text { days after anthesis to maturity }\end{array}$ & 650 \\
\hline G1 & $\begin{array}{l}\text { Kernel number coefficient: Kernel number per unit weight } \\
\text { of stem (less leaf blades and sheaths) plus spike at anthesis ( } \mathrm{g}^{-} \\
{ }^{1} \text { ) }\end{array}$ & 18 \\
\hline G2 & $\begin{array}{l}\text { Kernel weight coefficient: Kernel filling rate under optimum } \\
\text { conditions }\left(\mathrm{mgday}^{-1}\right)\end{array}$ & 43 \\
\hline G3 & $\begin{array}{l}\text { Tiller death or spike number coefficient: Non-stressed dry } \\
\text { weight (g) of a single stem (excluding leaf blades and sheaths) } \\
\text { and spike weight }(\mathrm{g}) \text { when elongation ceases }\end{array}$ & 4.0 \\
\hline PHINT & $\begin{array}{l}\text { Phyllochron interval: Thermal time required between } \\
\text { emergences of two successive leaf tips }\left({ }^{\circ} \mathrm{C} \text { day }\right)\end{array}$ & 100 \\
\hline
\end{tabular}


Table.2 Comparison of observed and predicted yield (kg/ha) of wheat (WH 1021) by DSSAT model (2011-12)

\begin{tabular}{|c|c|c|c|c|c|c|c|c|c|c|c|c|}
\hline \multirow{2}{*}{ Treatments } & \multicolumn{3}{|c|}{ Grain yield (kg/ha) } & \multicolumn{3}{|c|}{ Biomass (kg/ha) } & \multicolumn{3}{|c|}{ Straw yield (kg/ha) } & \multicolumn{3}{|c|}{ Harvest Index (\%) } \\
\hline & Obs. & Sim. & Error \% & Obs. & Sim. & Error \% & Obs. & Sim. & Error \% & Obs. & Sim. & Error \% \\
\hline \multicolumn{13}{|c|}{ Variety: WH 1021} \\
\hline $\mathbf{I}_{1} \mathbf{F}_{\mathbf{0}}$ & 1498 & 1249 & -16.62 & 4616 & 4184 & -9.36 & 3118 & 2935 & -5.87 & 32.50 & 29.85 & -8.14 \\
\hline $\mathbf{I}_{1} \mathbf{F}_{1}$ & 2491 & 2245 & -9.88 & 7152 & 6545 & -8.49 & 4661 & 4300 & -7.75 & 34.82 & 34.30 & -1.48 \\
\hline $\mathbf{I}_{1} \mathbf{F}_{2}$ & 2984 & 3015 & 1.04 & 8270 & 8195 & -0.90 & 5286 & 5180 & -2.00 & 36.06 & 36.79 & 2.02 \\
\hline $\mathbf{I}_{\mathbf{1}} \mathbf{F}_{3}$ & 3240 & 3426 & 5.74 & 8793 & 9362 & 6.47 & 5553 & 5936 & 6.90 & 36.81 & 36.59 & -0.59 \\
\hline $\mathbf{I}_{1} \mathbf{F}_{4}$ & 3305 & 3698 & 11.89 & 9046 & 9965 & 10.17 & 5741 & 6267 & 9.17 & 36.54 & 37.11 & 1.55 \\
\hline $\mathbf{I}_{2} \mathbf{F}_{0}$ & 2050 & 1759 & -14.20 & 5855 & 5175 & -11.61 & 3805 & 3416 & -10.22 & 35.00 & 33.99 & -2.88 \\
\hline $\mathbf{I}_{2} \mathbf{F}_{1}$ & 3035 & 2841 & -6.39 & 8088 & 7781 & -3.80 & 5053 & 4940 & -2.24 & 37.50 & 36.51 & -2.63 \\
\hline $\mathbf{I}_{2} \mathbf{F}_{2}$ & 3564 & 3507 & -1.60 & 9152 & 9325 & 1.89 & 5588 & 5818 & 4.12 & 39.01 & 37.61 & -3.59 \\
\hline $\mathbf{I}_{2} \mathbf{F}_{3}$ & 3803 & 4012 & 5.50 & 9557 & 9963 & 4.25 & 5754 & 5951 & 3.42 & 39.79 & 40.27 & 1.21 \\
\hline $\mathbf{I}_{2} \mathbf{F}_{4}$ & 3910 & 4325 & 10.61 & 9873 & 10567 & 7.03 & 5963 & 6242 & 4.69 & 39.60 & 40.93 & 3.36 \\
\hline $\mathbf{I}_{3} \mathbf{F}_{0}$ & 2531 & 2240 & -11.50 & 6731 & 6384 & -5.15 & 4200 & 4144 & -1.33 & 37.62 & 35.09 & -6.72 \\
\hline $\mathbf{I}_{3} \mathbf{F}_{1}$ & 3665 & 3485 & -4.91 & 9199 & 9032 & -1.82 & 5534 & 5547 & 0.23 & 39.88 & 38.59 & -3.25 \\
\hline $\mathbf{I}_{3} \mathbf{F}_{2}$ & 4321 & 4251 & -1.62 & 10533 & 10752 & 2.08 & 6212 & 6501 & 4.65 & 41.37 & 39.54 & -4.43 \\
\hline $\mathbf{I}_{3} \mathbf{F}_{3}$ & 4635 & 4699 & 1.38 & 10977 & 11423 & 4.06 & 6342 & 6724 & 6.02 & 42.23 & 41.14 & -2.58 \\
\hline $\mathbf{I}_{3} \mathbf{F}_{4}$ & 4791 & 5012 & 4.61 & 11372 & 11856 & 4.25 & 6581 & 6844 & 3.99 & 42.13 & 42.27 & 0.33 \\
\hline Mean & \multicolumn{3}{|c|}{2994} & \multicolumn{3}{|c|}{8033} & \multicolumn{3}{|c|}{5038} & \multicolumn{3}{|c|}{36.78} \\
\hline SD & \multicolumn{3}{|c|}{996} & \multicolumn{3}{|c|}{2059} & \multicolumn{3}{|c|}{1077} & \multicolumn{3}{|c|}{3.03} \\
\hline CV\% & \multicolumn{3}{|c|}{33.27} & \multicolumn{3}{|c|}{25.64} & \multicolumn{3}{|c|}{21.39} & \multicolumn{3}{|c|}{8.25} \\
\hline Bias & \multicolumn{3}{|c|}{-3.933} & \multicolumn{3}{|c|}{86.32} & \multicolumn{3}{|c|}{90.25} & \multicolumn{3}{|c|}{-0.684} \\
\hline RMSE & \multicolumn{3}{|c|}{226.3} & \multicolumn{3}{|c|}{463.6} & \multicolumn{3}{|c|}{271.2} & \multicolumn{3}{|c|}{1.683} \\
\hline nRMSE (\%) & \multicolumn{3}{|c|}{6.81} & \multicolumn{3}{|c|}{5.38} & \multicolumn{3}{|c|}{5.12} & \multicolumn{3}{|c|}{4.42} \\
\hline d & & 0.9 & & & 0.99 & & & 0.9 & & & 0.99 & \\
\hline
\end{tabular}

Whereas, $\mathrm{I}_{1}=$ one irrigation at CRI stage, $\mathrm{I}_{2}=$ Two irrigations at CRI and heading stage, $\mathrm{I}_{3}=4$ irrigations at CRI, late tillering, heading and milking stage and $\mathrm{F}_{0}$ $=0 \mathrm{~kg} \mathrm{~N} / \mathrm{ha}, \mathrm{F}_{1}=50 \mathrm{~kg} \mathrm{~N} / \mathrm{ha}, \mathrm{F}_{2}=100 \mathrm{~kg} \mathrm{~N} / \mathrm{ha}, F_{3}=150 \mathrm{~kg} \mathrm{~N} / \mathrm{ha}$ and $\mathrm{F}_{4}=200 \mathrm{~kg} \mathrm{~N} / \mathrm{ha}$. 
Table.3 Comparison of observed and predicted leaf area index (LAI) and total no. of effective tillers $/ \mathrm{m}^{2}$ of late sown wheat by DSSAT model

\begin{tabular}{|c|c|c|c|c|c|c|}
\hline \multirow{2}{*}{ Treatments } & \multicolumn{3}{|c|}{ Leaf Area Index (LAI) } & \multicolumn{3}{|c|}{ Total effective tiller/m ${ }^{2}$} \\
\hline & Obs. & Sim. & Error \% & Obs. & Sim. & Error \% \\
\hline \multicolumn{7}{|c|}{ Variety: WH 1021} \\
\hline $\mathbf{I}_{\mathbf{1}} \mathbf{F}_{\mathbf{0}}$ & 2.28 & 1.92 & -15.79 & 216 & 180 & -16.84 \\
\hline $\mathbf{I}_{1} \mathbf{F}_{1}$ & 2.73 & 2.42 & -11.36 & 250 & 231 & -7.51 \\
\hline $\mathbf{I}_{1} \mathbf{F}_{2}$ & 2.95 & 2.63 & -10.85 & 266 & 262 & -1.65 \\
\hline $\mathbf{I}_{1} \mathbf{F}_{3}$ & 3.08 & 2.9 & -5.84 & 275 & 283 & 3.01 \\
\hline $\mathbf{I}_{1} \mathbf{F}_{4}$ & 3.13 & 3.02 & -3.51 & 280 & 295 & 5.51 \\
\hline $\mathbf{I}_{2} \mathbf{F}_{0}$ & 2.73 & 2.41 & -11.72 & 246 & 231 & -6.07 \\
\hline $\mathbf{I}_{2} \mathbf{F}_{1}$ & 3.33 & 2.82 & -15.32 & 289 & 260 & -9.91 \\
\hline $\mathbf{I}_{2} \mathbf{F}_{2}$ & 3.60 & 3.31 & -8.06 & 309 & 296 & -4.33 \\
\hline $\mathbf{I}_{2} \mathbf{F}_{3}$ & 3.75 & 3.69 & -1.60 & 316 & 321 & 1.47 \\
\hline $\mathbf{I}_{2} \mathbf{F}_{4}$ & 3.83 & 3.92 & 2.35 & 323 & 345 & 6.72 \\
\hline $\mathbf{I}_{3} \mathbf{F}_{0}$ & 2.98 & 2.51 & -15.77 & 283 & 249 & -12.03 \\
\hline $\mathbf{I}_{\mathbf{3}} \mathbf{F}_{1}$ & 3.65 & 3.62 & -0.82 & 333 & 305 & -8.41 \\
\hline $\mathbf{I}_{\mathbf{3}} \mathbf{F}_{2}$ & 4.00 & 4.21 & 5.25 & 358 & 325 & -9.21 \\
\hline $\mathbf{I}_{\mathbf{3}} \mathbf{F}_{\mathbf{3}}$ & 4.18 & 4.56 & 9.09 & 370 & 349 & -5.79 \\
\hline $\mathbf{I}_{3} \mathbf{F}_{4}$ & 4.28 & 4.69 & 9.58 & 377 & 378 & 0.16 \\
\hline Mean & \multicolumn{3}{|c|}{3.05} & \multicolumn{3}{|c|}{276} \\
\hline SD & \multicolumn{3}{|c|}{0.71} & \multicolumn{3}{|c|}{49.66} \\
\hline CV\% & \multicolumn{3}{|c|}{23.50} & \multicolumn{3}{|c|}{17.93} \\
\hline Bias & \multicolumn{3}{|c|}{-0.124} & \multicolumn{3}{|c|}{-12.15} \\
\hline RMSE & \multicolumn{3}{|c|}{1.074} & \multicolumn{3}{|c|}{21.41} \\
\hline nRMSE (\%) & \multicolumn{3}{|c|}{31.9} & \multicolumn{3}{|c|}{7.14} \\
\hline D & \multicolumn{3}{|c|}{0.94} & \multicolumn{3}{|c|}{0.99} \\
\hline
\end{tabular}

Fig.1 Comparison of simulated (DSSAT model) and measured results of (a) grain yield (GY) (b) biological yield (BY) (c) Straw yield (SY) (d) harvest index (HI) (e) leaf area index (LAI) (f) effective tillers of late sown wheat in 2011-12
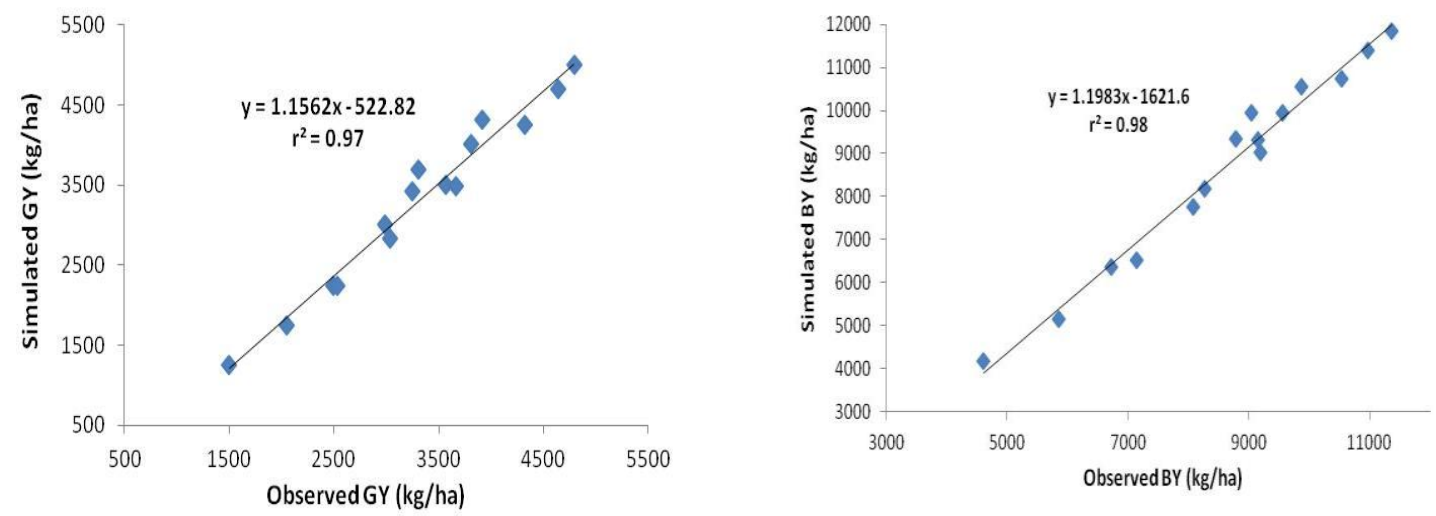
(a)

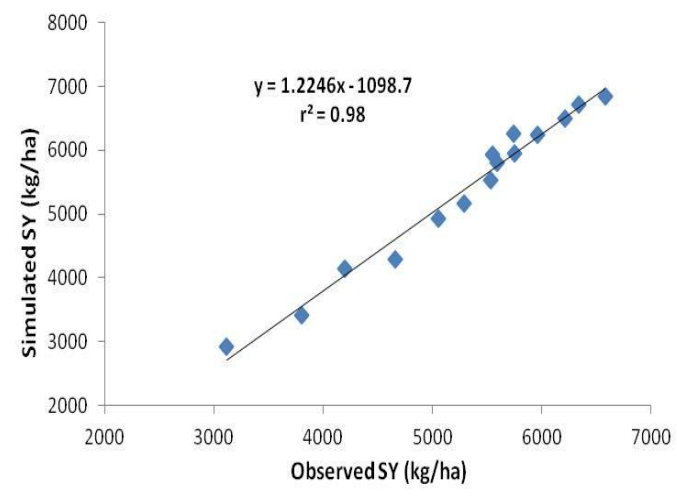

(c)

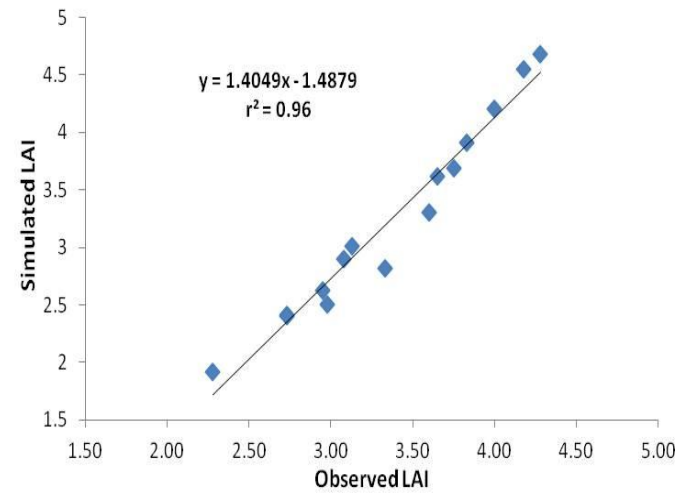

(e)

Comparison of harvest index of late sown wheat

Harvest index was simulated by the DSSAT model. Mean measured harvest index of wheat varied from $32.5 \%\left(\mathrm{I}_{1} \mathrm{~F}_{0}\right)$ to $42.2 \%$ $\left(\mathrm{I}_{3} \mathrm{~F}_{3}\right)$ among irrigation levels and dose of nitrogen combinations in 2011-12, while model simulated harvest index ranged between $29.8 \%\left(\mathrm{I}_{1} \mathrm{~F}_{0}\right)$ to $42.3\left(\mathrm{I}_{3} \mathrm{~F}_{4}\right)$ (Table 2 and Fig. 1d). The model underestimated the harvest index at lower doses of fertilizer i.e. 0 $\mathrm{kg} \mathrm{Nha}^{-1}$ and $50 \mathrm{~kg} \mathrm{Nha}^{-1}$ and overestimated at higher doses of fertilizer i.e. 150 and 200 $\mathrm{kg} \mathrm{N}^{-1}$ at all the irrigations levels during both the years of study. Error percent ranged between -8.14 $\left(\mathrm{I}_{1} \mathrm{~F}_{0}\right)$ to $3.36\left(\mathrm{I}_{2} \mathrm{~F}_{4}\right)$ in 2011-12. The calculated values of statistical indices, average error (Bias), root mean square error (b)

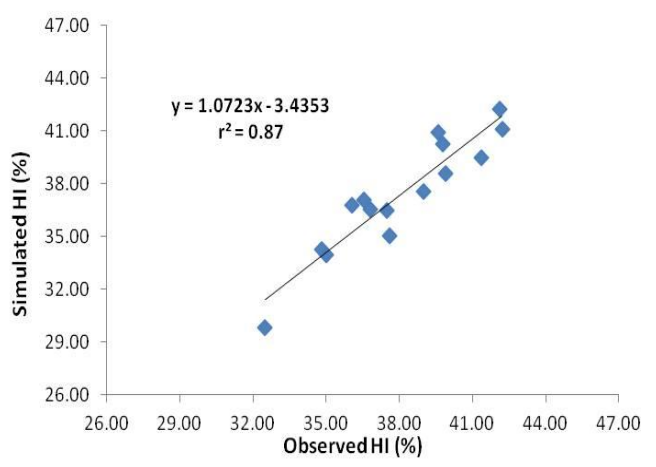

(d)

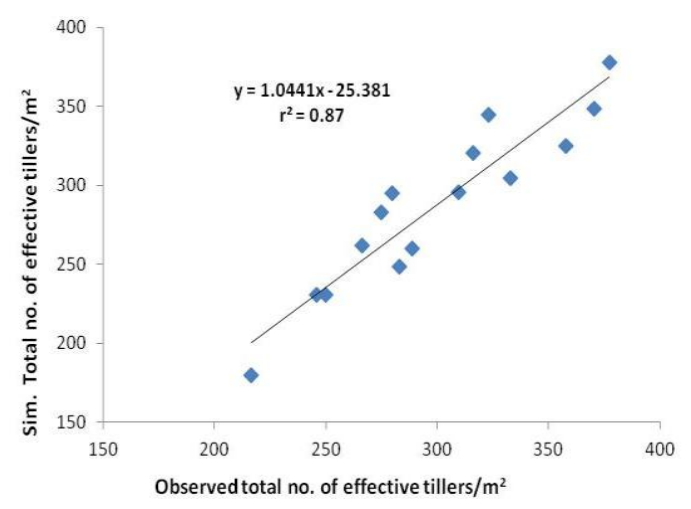

(f)

(RMSE), normalized RMSE (nRMSE), index of agreement (d) and coefficient of determination $\left(\mathrm{r}^{2}\right)$ were $-0.68,1.68,4.42 \%$, 0.99 and 0.87 .

\section{Comparison of leaf area index (LAI) of late sown wheat}

Leaf area index (LAI) was simulated by the DSSAT model (Table 3 and Fig. 1e). Mean measured LAI of wheat varied from 2.28 $\left(\mathrm{I}_{1} \mathrm{~F}_{0}\right)$ to $4.28\left(\mathrm{I}_{3} \mathrm{~F}_{4}\right)$ among irrigation levels and dose of nitrogen combinations in 201112, while model simulated LAI ranged between $1.92 \mathrm{~kg} \mathrm{ha}^{-1}\left(\mathrm{I}_{1} \mathrm{~F}_{0}\right)$ to $4.69\left(\mathrm{I}_{3} \mathrm{~F}_{4}\right)$. CERES-Wheat underestimated the LAI at one irrigation levels with all the dose of fertilizer. Error percent ranged between $-15.79\left(\mathrm{I}_{1} \mathrm{~F}_{0}\right)$ to $9.58\left(\mathrm{I}_{3} \mathrm{~F}_{4}\right)$ in 2011-12. The calculated values 
of statistical indices, average error (Bias), root mean square error (RMSE), normalized RMSE (nRMSE), index of agreement (d) and coefficient of determination $\left(\mathrm{r}^{2}\right)$ were -0.124 , 1.074, 31.9\%, 0.94 and 0.96 .

\section{Comparison of total no. of effective tillers $/ \mathbf{m}^{2}$}

Total no. of effective tillers $/ \mathrm{m}^{2}$ was simulated by the DSSAT model. Mean measured total effective tillers of wheat varied from 216 $\left(\mathrm{I}_{1} \mathrm{~F}_{0}\right)$ to $377\left(\mathrm{I}_{3} \mathrm{~F}_{4}\right)$ among irrigation levels and dose of nitrogen combinations during 2011-12, while model simulated total effective tiller $/ \mathrm{m}^{2}$ ranged between $180\left(\mathrm{I}_{1} \mathrm{~F}_{0}\right)$ to $378\left(\mathrm{I}_{3} \mathrm{~F}_{4}\right)$ (Table 3 and Fig. $1 \mathrm{f}$ ). The model underestimated the total effective tillers at lower doses of fertilizer i.e. $0 \mathrm{~kg}$ $\mathrm{Nha}^{-1}$ and $50 \mathrm{~kg} \mathrm{Nha}^{-1}$ and overestimated at higher doses of fertilizer i.e. 150 and $200 \mathrm{~kg}$ $\mathrm{N}^{-1}$ at all the irrigations levels. Error percent ranged between $-16.84\left(\mathrm{I}_{1} \mathrm{~F}_{0}\right)$ to $6.72\left(\mathrm{I}_{2} \mathrm{~F}_{4}\right)$. The calculated values of statistical indices, Bias, RMSE, nRMSE, d-stat and $\mathrm{r}^{2}$ were 12.15, 21.41, 7.14\%, 0.99 and 0.87, respectively.

Leaf area index (LAI) and total effective tillers $/ \mathrm{m}^{2}$ was very well simulated by DSSAT model (Table 3 and Fig. 1e and f). DSSAT underestimated the growth parameters like LAI, effective tillers and nitrogen uptake at lower dose of nitrogen because of less yields. Normalized RMSE (nRMSE) was less than $10 \%$ except in all parameters except LAI, where nRMSE was very high. But index of agreement was very close to one, it indicate the vigourness of the model. Similarly, the value of coefficient of determination $\left(\mathrm{r}^{2}\right)$ was 0.96 for LAI, 0.87 for total no. of effective tillers $/ \mathrm{m}^{2}$ and 0.95 for total nitrogen uptake indicates the robustness of the model.

In conclusion, the model underestimated the grain, biological, straw yield, harvest index, total number of effective tillers, LAI at control i.e. $0 \mathrm{~kg} \mathrm{~N} / \mathrm{ha}$ and lower $\mathrm{N}$ rates i.e. 50 $\mathrm{kg} \mathrm{N} / \mathrm{ha}$ in combination with all irrigations levels but overestimate all these parameters with higher dose of $\mathrm{N}$ i.e. 150 and $200 \mathrm{~kg}$ $\mathrm{N} /$ ha with all irrigation levels. The error was within -15 to $+15 \%$ in almost all parameters. The value of statistical indices, i.e. root mean square error, normalized root mean square error, index of agreement and coefficient of determination indicates the robustness of the model in simulation of wheat yield. However, model needs still improvement in simulation of late sown wheat in Hisar condition.

\section{References}

Alam, P., Satyender Kumar, Ali, N., Manjhi, R.P., Nargis Kumari, Lakra, R.K. and Izhar, T. 2013. Performance of wheat varieties under different sowing dates in Jharkhand. J. Wheat Res., 5(2): 61-64.

Ambose, J.R. and Rosech, S.E. 1982. Dynamic estuary of model performance, J. Environ. Ecol., 108-109 pp.

Andarzian, B., Gerrit, H., Bannayan, M., Shirali, M. and Andarzian, B. 2014. Determining optimum sowing date of wheat using CSM-CERES-Wheat model. J. Saudi Society of Agri. Sci., 13: 15-26.

Anonymous. 2014-15. www.indiastat.com.

FAO. 2014-15. www.fao.org.

Jamieson, P.D., Porter, J.R. and Wilson, D.R. 1991. A test of computer simulation model ARC-WHEAT1 on wheat crops grown in New Zealand. Field Crops Res., 27: 337-350.

Jones, J.W., Hoogenboom, G., Porter, C.H., Boote, K.J., Batchelor, W.D., Hunt, L.A., Wilkens, P.W., Singh, U., Gijsman, A.J. and Ritchie, J.T. 2003. DSSAT Cropping System Model. European J. Agron., 18: 235-265.

Khan, M.B., Ghurchani, M., Hussain, M. and Mahmood, K. 2010. Wheat seed 
invigoration by pre-sowing chilling treatments. Pakistan J. Botany, 42: 1561-1566.

Nain, A.S. and Kersebaum K.C. 2007. Calibration and validation of CERES model for simulating water and nutrients in Germany in Modelling Water and Nutrient Dynamics in SoilCrop Systems, chapter 12, pp. 161-181, Springer, Amsterdam, The Netherlands.

Solaimani, K. 2009. Rainfall-runoff prediction based on artificial neural network (a case study: Jarahi Watershed). J. Agri. Environ. Sci., 5: 856-865.

Thorp, K.R., DeJonge, K.C. and Kaleita, A.L. 2008. Methodology for the use of DSSAT models for precision agriculture decision support. Computers and Electronics in Agri., 64: 276-285.

Timsina, J., Godwin, D., Humphreys, E.,
Singh, Y., Singh, B., Kukal, S.S. and Smith, D. 2008. Evaluation of options for increasing yield and water productivity of wheat in Punjab, India using the DSSAT-CSM-CERESWheat model. Agricultural Water Management, 95: 1099-1110.

Willmott, C.J., Akleson, G.S., Davis, R.E., Feddema, J.J., Klink, K.M., Legates, D.R., Odonnell, J. and Rowe, C.M. 1985. Statistic for the evaluation and comparison of models. J. Geophysical Res., 90: 8995-9005.

Yang, Y., Watanabe, W., Zhang, X., Zhang, J., Wang, Q. and Hayashi, S. 2006. Optimizing irrigation management for wheat to reduce groundwater depletion in the piedmont region of the Taihang Mountains in the North China Plain. Agri. Water Management, 82: 225-44.

\section{How to cite this article:}

Mukesh Kumar, R.K. Pannu, Raj Singh, Bhagat Singh, A.K. Dhaka and Rajeev. 2017. Prediction of Growth and Yield of Late Sown Wheat Using DSSAT (v4.5) Model Under Western Zone of Haryana. Int.J.Curr.Microbiol.App.Sci. 6(3): 1687-1696. doi: https://doi.org/10.20546/ijcmas.2017.603.194 